\title{
ゲル化反応を利用した高気孔率発泡金属作製における使用粉末粒度の影響
}

\author{
清水 透的 1 , 松崎 邦男的 1 , 菊地 薫的1, 金武 直幸的 2 \\ 站1 産業技術総合研究所 先進製造プロセス研究部門，干305-8564つくば市並木1-2-1つくば東事業所. \\ 虹名古屋大学大学院工学研究科マテリアル理工学専攻, テ 464-8603 名古屋市千種区不老町.
}

\section{Method to Produce High Porosity Metal Foam using Gelation and Effect of Used Powder Grain Size}

\author{
Toru Shimizu ${ }^{\text {मे } 1}$, Kunio Matsuzaki ${ }^{\text {tै }}$, Kaoru Kikuchi ${ }^{\text {th } 1}$ and Naoyuki Kanetake ${ }^{\text {th } 2}$ \\ ${ }_{4}$ National Institute of Advanced Industrial Science and Technology, 1-2-1 Namiki, Tsukuba 305-8564, Japan. \\ $\star^{2}$ Department of Material Science and Engineering, Graduate School of Engineering, Nagoya University, \\ Furo-cho, Chikusa-ku, Nagoya 464-8603, Japan.
}

Received December 4, 2009

\section{SYNOPSIS}

Production process of high porosity closed cell type metal foam is developed using a hydrogel binder. Using this process, the stainless steel foam is produced with its porosity more than $98 \%$. However, we need to use fine metal powder to produce high porosity metal foam, and as the result, the production cost of the foam is increased. Therefore, the metal foams are produced using different grain size powders and their foam properties are compared with each other. As the result, finer powders should be used for producing high porosity metal foam. However, relatively coarse powder can be used for producing $95 \%$ porosity metal foam, decreasing the production cost of the foam. This cost reduction can expand the applications of this material.

\section{KEY WORDS}

metal foam, SUS316 stainless steel, water base binder, hydro-gel, grain size

\section{1 緒言}

高気孔率発泡金属は軽量であり，断熱性，吸音性および磁 気遮蔽特性に優れるため幅広い応用が期待される.このよう な発泡材料を作製する手法 ${ }^{1)} と し て ，(1)$ 溶湯，あるいは金属 粉を溶融温度まで上昇させて作製する手法, (2)CVDやメッキ による方法, (3)粉末金属から焼結して作製する手法, の3つ が開発されている. 1 つ目は溶湯を機械的に攪拌したり，発 泡剤を溶湯中に添加して, 発泡させながら凝固させる ${ }^{2)}$, あ るいは，金属粉と発泡剂を混合，加圧固化し溶融と同時に発 泡させて発泡体を作製する方法もあり ${ }^{3,4)}$ ，二つ目の方法では ニッケルのオープンセル発泡体が作られ, 電池電極等に広く 利用されている5,6).しかし, 合金や融点の高い金属の発泡体 作製を試みる場合, 三つ目の手法が有効である。この方法で は粉末とバインダーのコンパウンド, あるいはスラリーを利 用し, 焼結により発泡材料を作製することが多い.このよう な方法としてスラリーを発泡させる手法 ${ }^{7}$, 発泡ウレタン原 料中に金属粉を混ぜ込む手法 ${ }^{8)}$ ，ポリウレタンをテンプレー 卜とする方法などが提案されている.このように様々な手法 が考案, 開発されてきている中, 我々はできるかぎり気孔壁
を残したクローズドセル構造に近い構造を持ち, より高気孔 率が達成可能な手法を開発してきた。この方法は金属粉スラ リーに発泡剂を混入し，そのスラリーをゲル化したあとに発 泡・乾燥させて前躯体を作製する方法 ${ }^{9,10)}$ で, 十分に微細な金 属粉を使用することにより $98 \%$ を超える高気孔率の達成が可 能である.この方法によりステンレス鋼による高気孔率発泡 体を作製したが，微細な金属粉は高価であり，工業的実用材 料としての利用を検討する場合, より経済的な粉末の利用が 求められる。 そこで本報では, 使用する粉末の平均粒径を $3 \mu \mathrm{m}$ から $11 \mu \mathrm{m}$ まで変化させ, 粉末粒径, 作製条件の気孔構 造, 機械的特性への影響を調査した。

\section{2 バインダーのゲル化反応による発泡金属の作製}

\section{1 作製手法の概要}

この発泡体作製プロセスをFig.1に示す.この方法では, 凍 結・解凍プロセスによりゲル化するPVA (ポリビニールアル コール)の水溶液に発泡剤を混合したものをバインダーとし て用いる. 分子量が 80000 を超えるPVAの水溶液は, 凍結後 24時間程度保持し解凍することによって, 弾性に富む強固な 


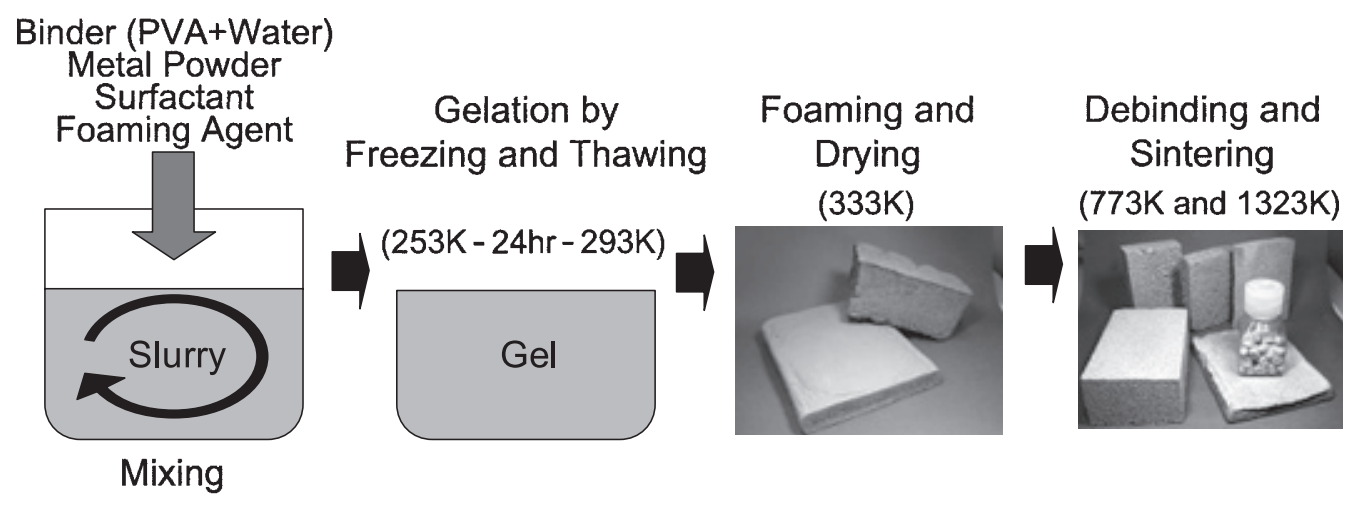

Fig.1 Process to produce high porosity metal foam using hydro-gel.

Table 1 Used feedstock for the stainless steel foam.

\begin{tabular}{|l|l|}
\hline $\begin{array}{l}\text { Stainless Steel } \\
\text { Powder }\end{array}$ & Epson Atmix Co. SUS316L PF3F,PF5F,PF10F,PF20F \\
\hline PVA solution & $\begin{array}{c}\text { Water solution of PVA (8wt\%) } \\
\text { (PVA: Nippon Gosei Co. NH-26) }\end{array}$ \\
\hline Foaming Agent & Normal Pentane ( Wako Chem. Co.) \\
\hline Surfactant & Neutral Detergent(Saraya Chem. Co. YASHINOMI) \\
\hline
\end{tabular}

Table 2 Used stainless steel powder and their gain size.

\begin{tabular}{|c|c|c|c|c|}
\hline \multirow{2}{*}{ Powder Grade } & \multicolumn{2}{|c|}{ Particle size } & distribution & \multicolumn{2}{c|}{$\begin{array}{c}\text { Sintering Temperature } \\
\text { ny }\end{array}$} \\
\cline { 2 - 4 } & D10 & D50 & D90 & 1323 \\
\hline PF3F & 1.4 & 3.2 & 5.0 & 1373 \\
\hline PF5F & 2.2 & 4.9 & 8.0 & 1423 \\
\hline PF10F & 3.0 & 6.3 & 12.0 & 1473 \\
\hline PF20F & 3.6 & 10.9 & 25.0 & \\
\hline
\end{tabular}

ゲルとなり, 凍結と解凍を繰り返すことによりさらに強固な ゲルとなる ${ }^{11)}$.このPVA水溶液に炭化水素系発泡剂, 界面活 性剂を混合したバインダーに金属粉を混ぜてさらに攢汼する. 発泡剤には $342 \mathrm{~K}$ に沸点を持つノルマルヘキサン, $312 \mathrm{~K}$ に沸 点を持つノルマルペンタン, その他 $300 \mathrm{~K}$ から $350 \mathrm{~K}$ に沸点 を持つ素材を発泡剤として使用できる. 界面活性剤には一般 的な中性洗剤の利用が可能であり, 水に不容解の発泡剤をコ ロイド状に分散させる，このように作製したスラリーを凍 結・解凍プロセスによりゲル化する. 解凍後, ゲル化したス ラリーを $333 \mathrm{~K}$ から $358 \mathrm{~K}$ の温度で保持して発泡させる.この 発泡処理により膨張・乾燥し，スポンジ状になった前躯体を 得る、その前躯体を混入した金属粉に応じた条件で焼結処理 することにより発泡金属が作製できる. PVA等のバインダー 成分は焼結途中において分解除去される

2.2 ステンレス発泡金属作製条件

ステンレス鋼発泡金属の作製において, 金属粉の平均粒径 の異なる 4 種のグレードの金属粉を用いた. 作製に使用した ステンレス鋼粉, PVA 水溶液, 界面活性剤を Table 1 に示す. ステンレス鋼粉にはエプソンアトミックス株式会社の 4 種類
のグレードのSUS316粉末を用いた.グレードと粒径分布の 関係を Table 2 に示す．スラリー中の PVA 水溶液 ( $85 \mathrm{vol} \%)$, 発泡剂 (7.5 vol\%), 界面活性剂 (7.5 vol\%)の配合割合は一定と し，そのスラリーに混入する金属粉の体積割合を 10, 15, 20, $30 \mathrm{vol} \%$ と変化させた. このようにして作製したスラリーを $5 \mathrm{~cm}$ 角の容器に入れ, $-10^{\circ} \mathrm{C}$ の冷凍庫で 24 時間保持して凍 結する. 解凍は室温で行い, およそ2-3 時間程度で解凍後, 恒温槽で発泡処理を行う. 発泡剤にノルマルペンタンを使用 するため, 発泡処理温度は $328 \mathrm{~K}$ とした. 発泡処理において はゲル化したスラリー表面の乾燥を防ぐため, ビニール袋で 包んで加熱する. 発泡処理は 1 時間程度で終了するが，その 後, 袋から取り出し, そのまま恒温槽で保持して乾燥処理を 行う。このように作製された前躯体は不定形な形状となるた め, ブロック状に切り出し燒結する. 焼結は真空炉で行い, バ インダーは焼結過程の前半で分解する. 焼結における炉の加 熱スケジュールをFig.2に示す.金属粉の焼結性は粒度により 大きく影響をうけるため, 使用した粉末のグレードにより焼 結温度を変化させた. 焼結温度をTable 2 に示したが, その温 度で 30 分保持して焼結を終了する. 


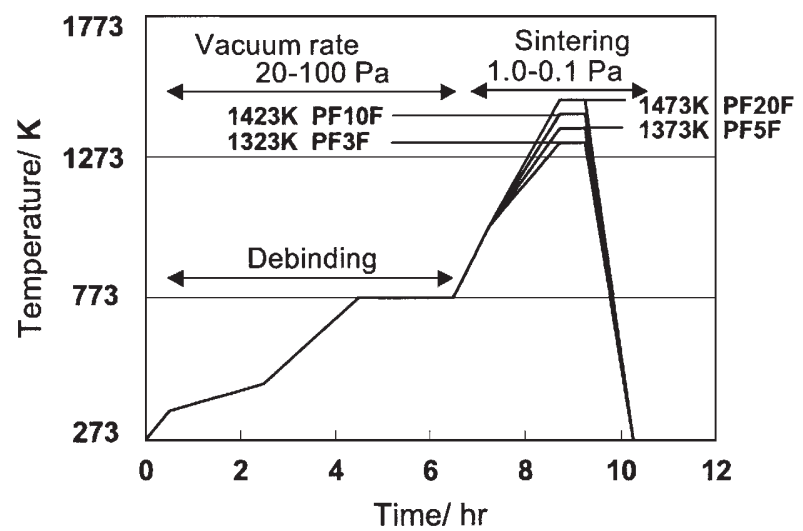

Fig.2 Debinding and sintering conditions for stainless steel foam.

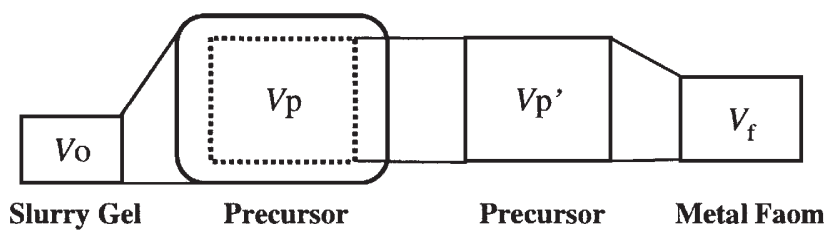

Fig.3 Volume of slurry gel, precursor, metal foam and evaluation of expansion rate.

3 作製した前躯体，および発泡体の評価

\section{1 発泡倍率, および気孔率の評価}

発泡前躯体の発泡倍率, 焼結後の発泡倍率, 焼結後の気孔 率を評価した. 評価はFig.3の様に行った. 前駆体の発泡倍率 は発泡前躯体の体積 $V_{\mathrm{p}}$ を発泡前のスラリーの体積 $V_{\mathrm{o}}$ で割つ た值とした. 焼結体の発泡倍率は前躯体より切り出した直方 体の体積を $V_{\mathrm{p}}{ }^{\prime}$ ， その直方体を焼結した発泡体の体積を $V_{\mathrm{f}}$ と すると, 前躯体の発泡倍率に $V_{\mathrm{f}} / V_{\mathrm{p}}$, を掛けた值とした. また, 焼結体の重量を $W_{\mathrm{f}}$, ステンレス鋼の密度を $\rho_{\mathrm{sus}}$ とした。焼結 体のかさ密度, 気孔率は式(3),(4)より評価した。

Expansion rate of precursor $=V_{\mathrm{p}} / V_{\mathrm{o}}$

Expansion rate of metal foam $=\left(V_{\mathrm{p}} / V_{\mathrm{o}}\right)\left(V_{\mathrm{f}} / V_{\mathrm{p}}{ }^{\prime}\right)$

Bulk density $=W_{\mathrm{f}} / V_{\mathrm{f}}$

Porosity $(\%)=100-100 \cdot W_{\mathrm{f}} /\left(\rho_{\text {sus }} \cdot V_{\mathrm{f}}\right)$

発泡剤の投入量を $7.5 \mathrm{vol} \%$ に固定し，金属粉の粒径，金属粉 の割合を変化させて, 前躯体の発泡倍率, 焼結体の発泡倍率, かさ密度, 気孔率を評価した。作製条件と前躯体発泡倍率の 関係をFig.4に示す. 前躯体の発泡倍率は 4 倍から 8 倍の間で 金属粉粒度が小さいほど発泡倍率は高くなる傾向がある.金 属粉は発泡したゲルの膜面に分散して気孔を安定にすると考 えられるが，同時に焼結後膜面を残した気孔構造となる. 表 面張力のバランスから金属粉が小さいほど分散する膜面が広 くなるため，発泡倍率が高くなると考えられる。しかし，金 属粉の体積割合の増加も同様の効果があると考えられるがそ の影響は小さい.作製条件之発泡金属発泡倍率の関係をFig.5 に示す，金属粉粒径が小さい PF 3 Fから PF10Fでは，発泡倍

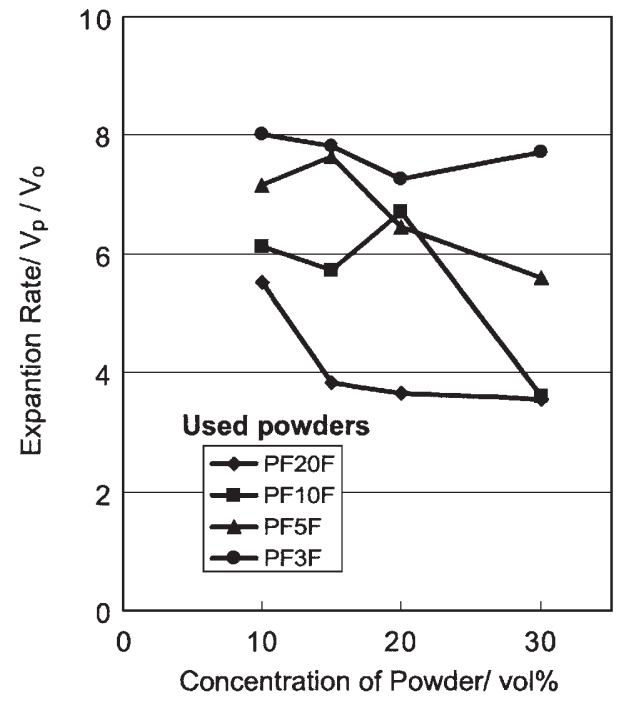

Fig.4 Expansion rate of precursors.

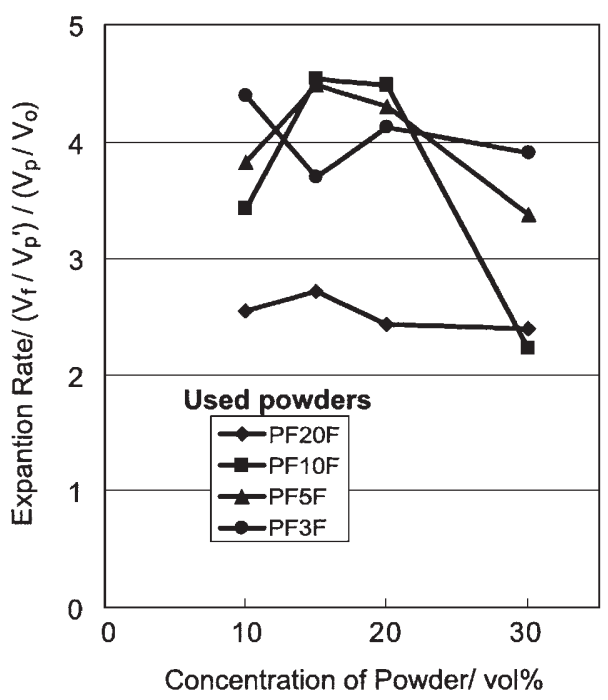

Fig.5 Expansion rate of stainless steel foams.

率はほぼ4倍となっているが，PF20Fの場合は発泡倍率が小 さく2倍程度となる. Fig.6に作製条件と発泡金属の気孔率の 関係を示す．前躯体作製時の発泡倍率と同様に，発泡金属の 気孔率は使用する金属粉の粒径が小さいほど, 金属粉の体積 割合が小さいほど高くなる傾向がある。しかし，平均粒径 $5 \mu \mathrm{m}$ 以下のPF3Fから PF5Fの金属粉を用いた場合には気孔率 に大差は無く, 達成可能気孔率は $98 \%$ 程度であり, 平均粒径 $10 \mu \mathrm{m}$ 以上の PF $20 \mathrm{~F}$ を使用した場合は $96.5 \%$ 程度が限界とな る.

\section{2 気孔構造と気孔径の評価}

前躯体の気孔構造写真をFig.7に示す.写真に見られるよう に気孔の構造は金属粉体積割合より変化し, 特に金属粉体積 割合が $30 \mathrm{vol} \%$ の範囲において前躯体の気孔径が小さくなる 傾向がある. 金属粉の粒径による傾向はこの写真では判断し にくい. また, 焼結した発泡金属の気孔構造写真をFig.8に示 


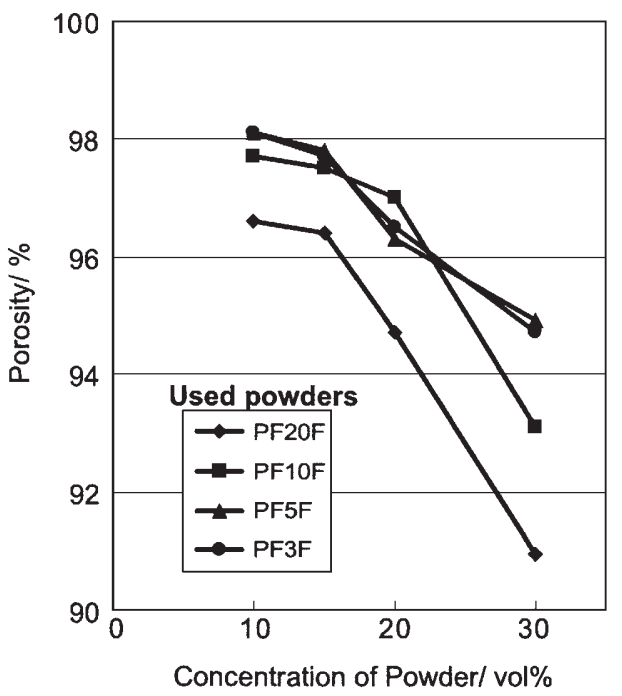

Fig.6 Porosities of the stainless steel foams.

す. 高気孔率の発泡金属はそのままでは切断および観察が困 難であるため, エポキシ樹脂を含浸して硬化させたものを切 断, 研磨して観察した. 発泡体の形状は気泡の膜面を残して おり,クローズドセルに近い構造を持っているが, 樹脂の含 浸が可能な事から，基本的に連通気孔となっている．また， Fig.8から評価される平均気孔径を Fig.9に示す. 気孔径は単 位長さの直線に交差する気孔壁の数から推定した. 気孔径は 金属粉体積割合に大きく影響され，金属体積割合が多いほど
小さくなる，一方，使用する金属粉末の粒子径の影響は小さ い.

セル壁の厚さは気孔がクローズドセル構造であると仮定す れば, 気孔率と気孔径より推定できる. 気孔が均一なケルビ ンの 14 面体より構成されるとしてこの推定を試みる. 14 面 体の一辺の長さを $L$ とすればその体積 $V_{\mathrm{K}}$ は式(5)のようにな る. また, 気孔率 $P$ と一辺の長さ $L$, セル壁の厚さ $t$ の関係は 式(6)のようになる ${ }^{10)}$. さらに, 一つのセルの体積 $V_{\mathrm{K}}$ と等し い体積の球の直径 $\phi$ は式(7)のようになる.これより, 気孔径 $\phi$ と気孔率 $P$, およびセル壁厚さ $t$ は式(8)の関係で表される.

$$
\begin{aligned}
& V_{\mathrm{K}}=11.31 \cdot L^{3} \\
& P(\%)=100 \cdot(1-1.18 \cdot t / L) \\
& V_{\mathrm{K}}=\pi \phi^{3} / 6 \\
& P(\%)=100 \cdot(1-3.29 \cdot t / \phi)
\end{aligned}
$$

式 (8) で予想される気孔率とセル壁厚さの関係を実測值とと もにFig.10に示す．図によれば粒子径の大きいPF20Fによる 発泡体の場合, セル壁の厚さは $15-10 \mu \mathrm{m}$ となり, 粒子径の 小さいPF10Fの場合 $10-6 \mu \mathrm{m}$ 程度となる.さらに粒子径の小 さいPF5F, PF3Fの場合セル壁の厚さは8-5 $\mu \mathrm{m}$ 程度となる.こ のセル壁の推定值は，セル壁に粉末がほぼ一層に並んで構成 され，さらに焼結により粒径が若干大きくなっているとすれ ば, 大まかな推定法であるにもかかわらず妥当な值となって いる. また，Fig.11にセル壁の拡大写真を示す。この写真か

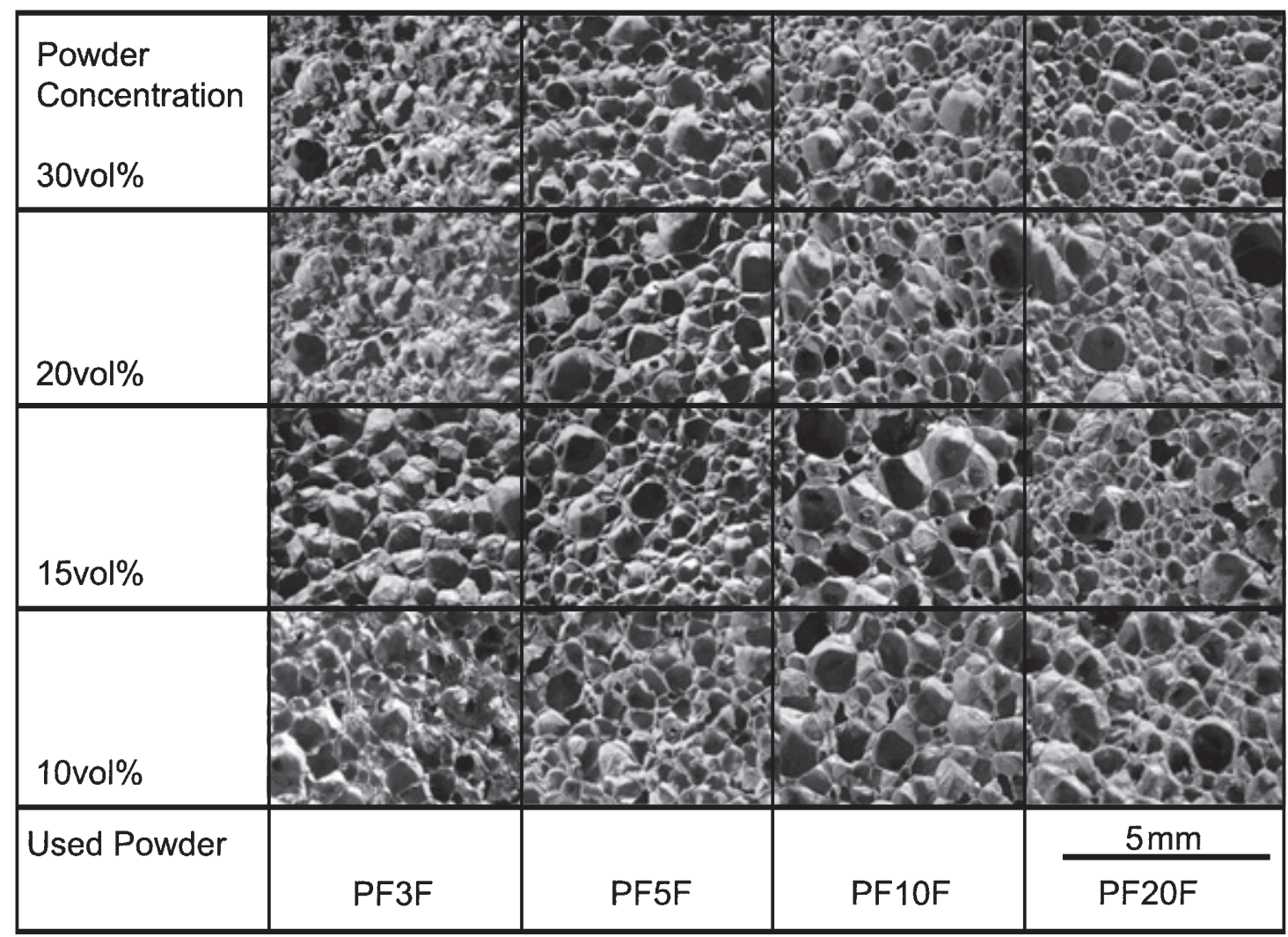

Fig.7 Cell structures of precursors when powder concentration in slurry and grain size are changed. 


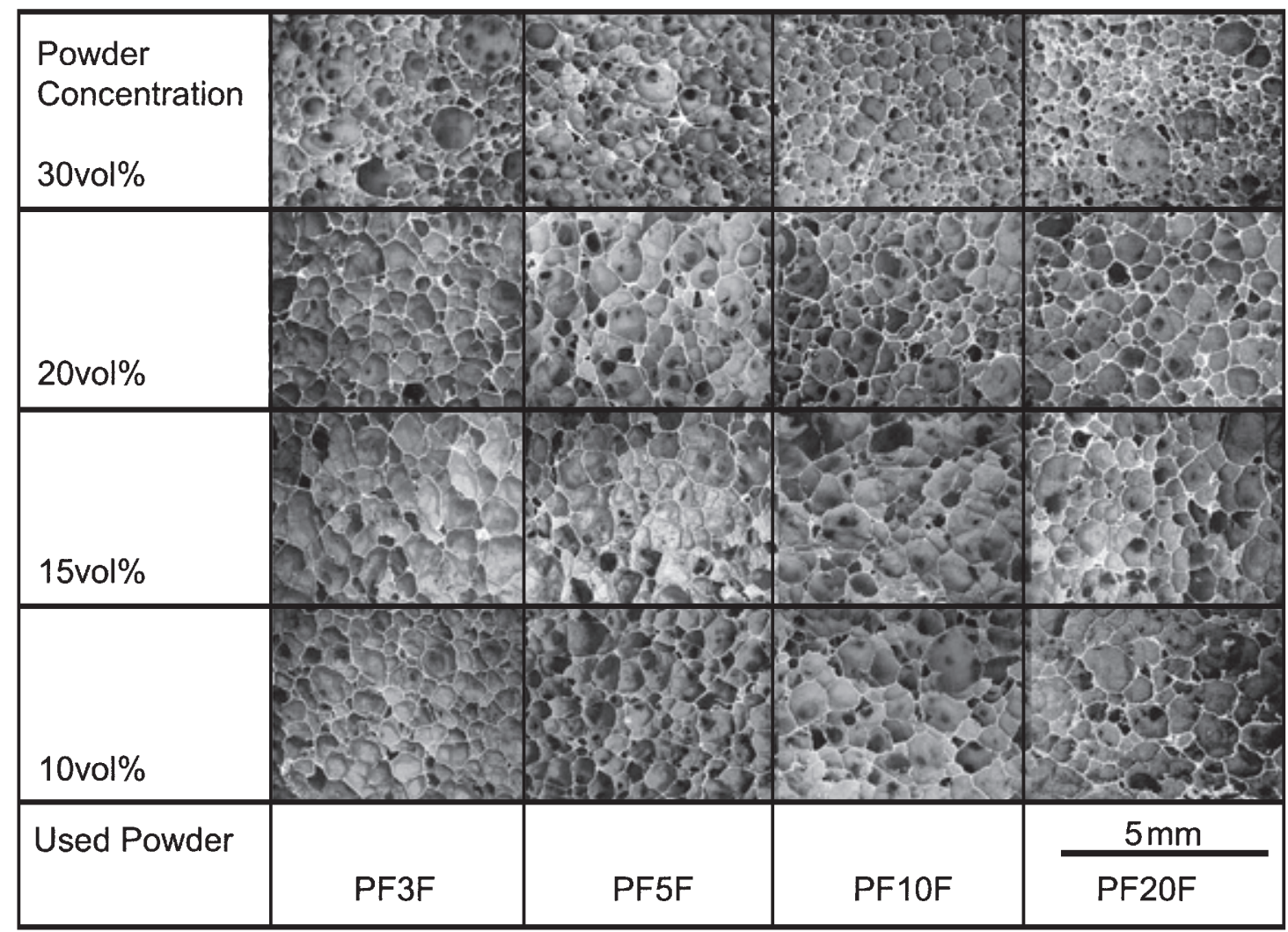

Fig.8 Cell structures of stainless steel foams when powder concentration in slurry and grain size are changed.

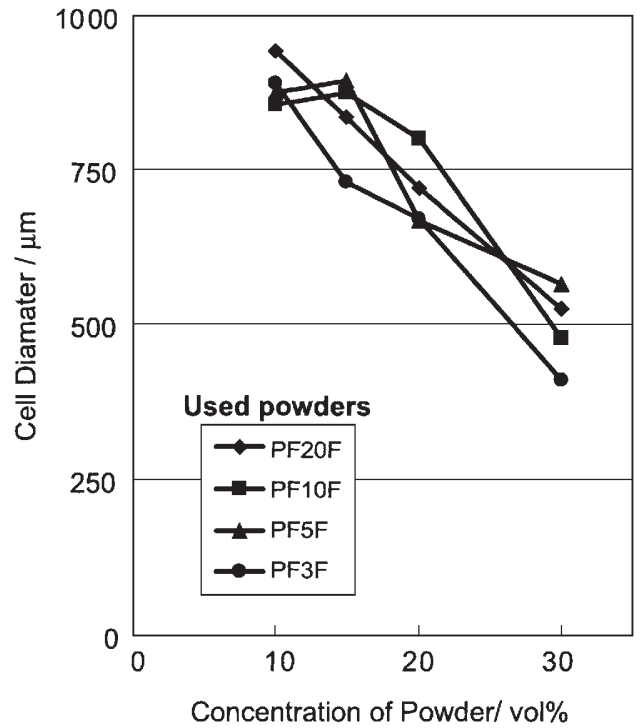

Fig.9 Relation of powder concentration and cell diameter when grain size is changed.

らもセル壁の推定がほぼ妥当と思われる.これらのことより, 高気孔率の達成には粒径の小さい粉末を使用してセル壁を薄 くすること重要であることが確認できる.

3.3 機械的特性の評価と気孔率の影響

粒径の異なる粉末から作製した試料より気孔率の異なる試

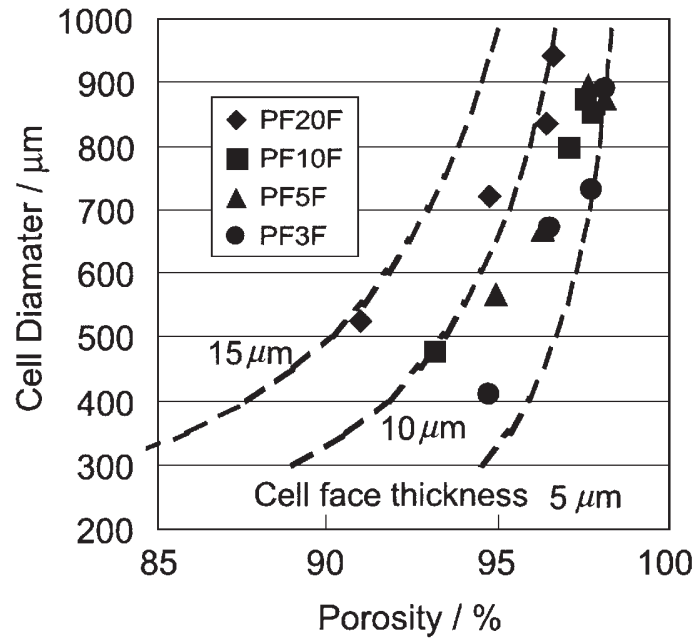

Fig.10 Relation of porosity, cell diameter and cell wall thickness.

験片を切り出し，圧縮試験を行った．圧縮試験片は $15 \times 15 \times$ $25 \mathrm{~mm}$ の試験片とし, 圧縮速度は $10 \mathrm{~mm} / \mathrm{s}$ として試験した. 試 験装置には島津オートグラフ DS-10000Nを用いた。 PF3Fを 使用した発泡体の場合 $0.13 \mathrm{~g} / \mathrm{cm}^{3}$ から $0.42 \mathrm{~g} / \mathrm{cm}^{3}$ まで, PF5Fを 使用した発泡体の場合 $0.15 \mathrm{~g} / \mathrm{cm}^{3}$ から $0.40 \mathrm{~g} / \mathrm{cm}^{3}$ まで, PF10F を使用した発泡体の場合 $0.14 \mathrm{~g} / \mathrm{cm}^{3}$ から0.54 g/cm² まで, PF20F を使用した発泡体の場合 $0.25 \mathrm{~g} / \mathrm{cm}^{3}$ から $0.68 \mathrm{~g} / \mathrm{cm}^{3}$ までの密度 の試験片を準備し，圧縮試験を行った。それぞれの結果を 


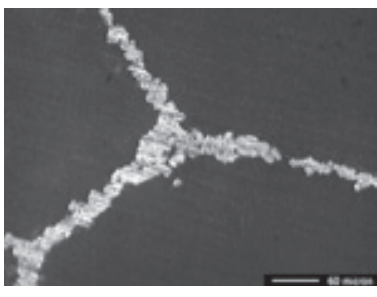

PF20F

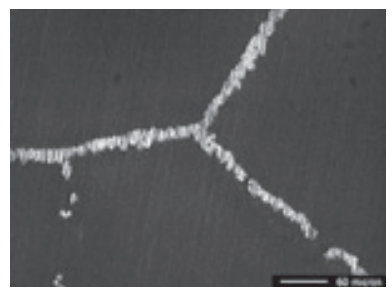

PF10F

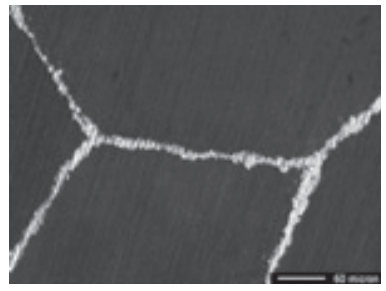

PF5F

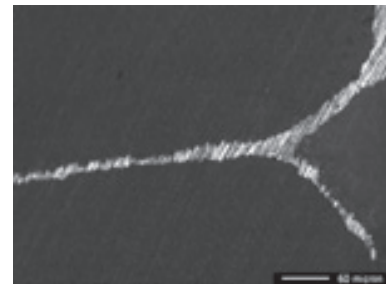

PF3F

Fig.11 Photographs of cell faces when grain size is changed (powder concentrations in slurry are 20 vol\%).
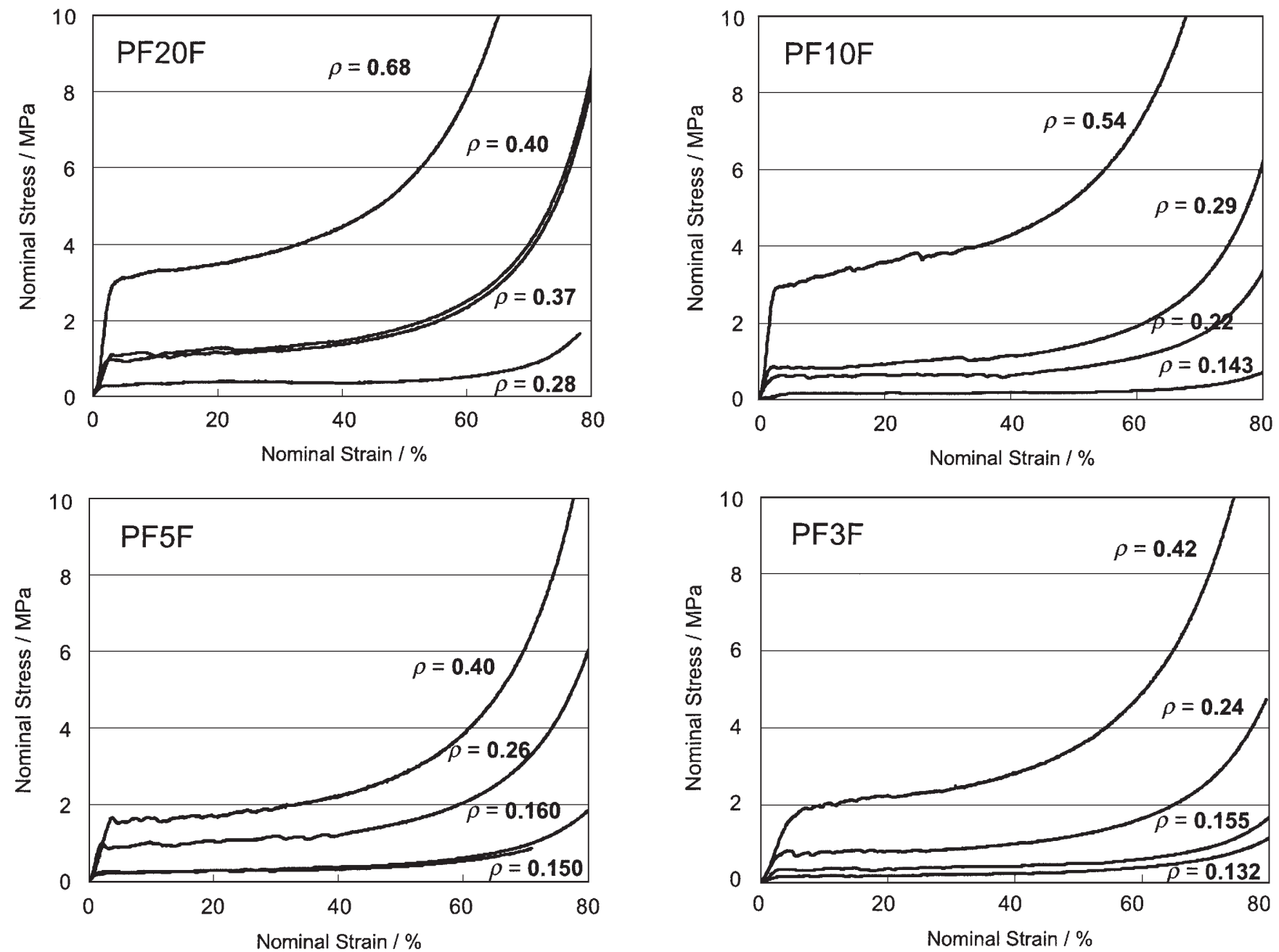

Fig.12 Stress-strain curve of stainless steel foams by compression test.

Fig.12に示す.どの試験結果においてもひずみ $40-50 \%$ まで, 変形抵抗は大きく増加せず，プラト一領域を示す．また，各 図で近い密度(例えば0.4あるいは 0.25 付近)の曲線を比較す ると, 粉末粒径の小さい PF3F と PF5Fの発泡体では良く似た 変形特性を示すが，PF20Fのように粉末粒径が大きい試料で は変形抵抗が低下する傾向が見られる。この試験結果をひず み $20 \%, 60 \%$ の場合の変形抵抗で評価し，密度と圧縮応力の 関係を Fig.13の両対数グラフに示す．PF3F，およびPF5Fに
よる発泡体の場合 $20 \%$ および $60 \%$ のいずれのひずみの変形 抵抗も値がほぼ等しく，密度の二乗に比例している．PF10F による発泡体の場合, 密度 $0.25 \mathrm{~g} / \mathrm{cm}^{3}$ 以上においては両ひず みにおける变形抵抗と密度の関係は，ほぼPF3FやPF5Fの場 合と一致し, 密度の二乗に比例する. しかし, それ以下の密

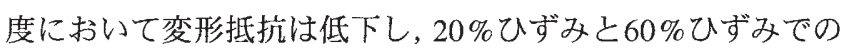
変形抵抗の差は小さくなる.さらにPF20Fの場合, $0.35 \mathrm{~g} / \mathrm{cm}^{3}$ 以上の密度においてはほぼ密度の二乗に比例するものの, 他 


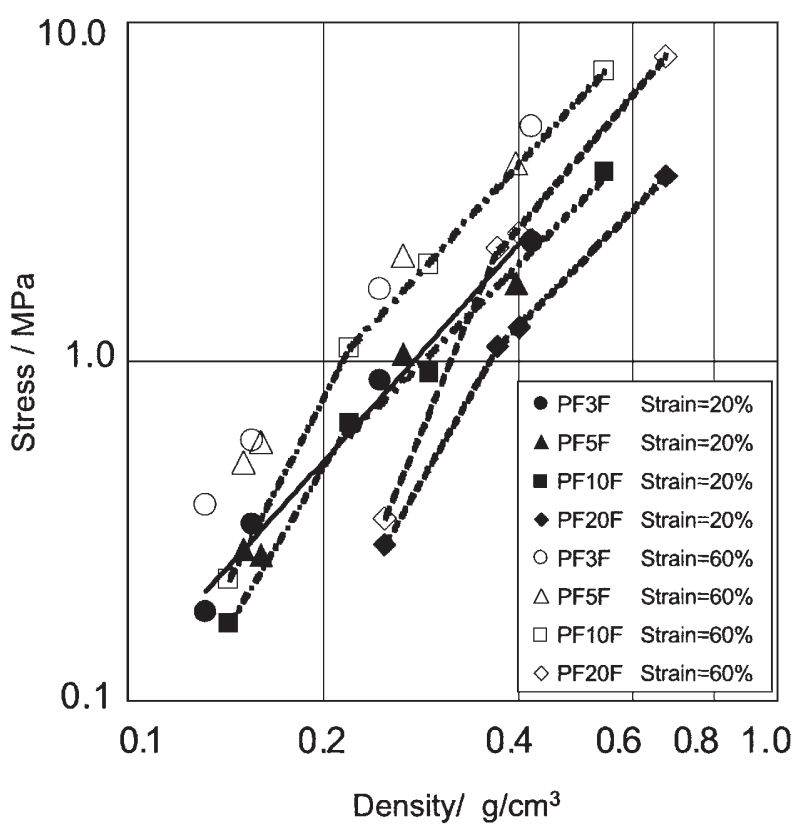

Fig.13 Relation of yield stress and density on stainless steel foam.

の発泡体と比較して変形抵抗は小さい. そして, それ以下の 密度においては圧縮応力はさらに低下し，20\%ひずみと60\% ひずみの変形抵抗の差は小さい. 以上の様に使用する粉末粒 子径が大きくなってくると, 同一密度でも変形抵抗が小さく なる傾向があり, また, ある密度以下で変形抵抗が密度の二 乗以上に低下する傾向がある．このことは，粒子径が大きく 体積割合が少ない場合, 発泡体の焼結時においてセル壁を構 成する粒子が疎になり，そのためセル壁の強度が低下するこ とによって起こる現象と推測する.

\section{4 結 論}

ゲル化反応を利用した発泡金属作製法において，使用する 金属粉の粒度と作製される発泡金属の特性について比較した。 金属粉の粉末粒径が小さくなるほど圧縮強度を維持したまま 高気孔率化が可能であり, 平均粒径 $5 \mu \mathrm{m}$ 以下の金属粉を用い た場合には $98 \%$ 程度の気孔率が達成可能である. 粉末粒径が 小さいほど高品位の発泡金属が作製可能であるが, その一方， 粉末のコストも高くなる.ここで作製される発泡金属作製手 法の実用化の見地からは, 使用する粉末をできる限り粗くし て，低コスト化を計ることが望ましい。ここでおこなった結 果からは, 密度が $0.3 \mathrm{~g} / \mathrm{cm}^{3}$ までは平均粒径 $6 \mu \mathrm{m}(\mathrm{PF} 10 \mathrm{~F})$ の粉 末を用いても,さらに小さい粉末を利用したものと同等の圧
縮強度を持つ発泡金属の作製が可能である.しかし，さらに 粗い平均粒径 $11 \mu \mathrm{m}$ (PF20F) を用いた場合, 圧縮強度は全体に 低下してしまう. また, 密度 $0.3 \mathrm{~g} / \mathrm{cm}^{3}$ 以下の発泡体で圧縮強 度を求める場合はさらに細かい平均粒径 $3 \mu \mathrm{m}$ (PF3F), $4 \mu \mathrm{m}$ (PF5F) を使用することが勧められる.

\section{文献}

1) J. Banhart: "Manufacture characterization and application of cellular metals and metal foams", Progress in Materials Science, 46(2001)599-632.

2) H. Ueno and S. Akiyama: "Effect of caluium addition on the foam-ability of molten aluminum", J. Jap. Inst. Light Metals, 37(1987)42-47.

3) J. Banhart, J. Baumeister, and M. Weber: "Damping properties of alminium froams", Materials Science and Engineering A, 205(1996)221-228.

4) N. Kanetake and M. Kobashi: "Inovative processing of porous and cellular materials by chemical reaction", Scripta Materialla, 54(2006)521-525.

5) V. Paserin, J. Shu, and S. Marcson: "Superior nickel foam production: Starting from raw material quality control", Porous Metals and Metal Foaming Technology, Proceedings of METFOAM2005, Kyoto, (2005)317-320

6) M. Honda: "Development of metal foam and upgrade of alkaline secondary cell performance", Materia, 38(1999)470474.

7) K. Hoshino, Y. Mayuzumi, and S. Wakita: "Production process of high strength spongy-like porous nickel plate", Japanese Patent Publication Number H1 1-269506.

8) C.S.Y. Jee, N. Ozguven, Z.X. Guo, and J.R.G. Evans: "Preparation of high porosity metal foams", Metallurgical and Materials Transaction B, 31B(2000) 1345-1351.

9) T. Shimizu and K. Matsuzaki: "Processing technology for high porosity closed cell metal foam", Porous Metals and Metal Foaming Technology, Proceedings of METFOAM2005, Kyoto, (2005) 191-194.

10) T. Shimizu and K. Matsuzaki: "Metal foam production process using hydro-gel and its improvement", Materials Science Form, 539-543(2007) 1845-1850.

11) M. Watase and M.K. Nishinari: "Large deformation of hydrogels of poly(vinyl alcohol), agarose and kappacarrageenan", Macro mol. Chem. Phys., 186(1985) 1081-1086. Table 1 Chemical composition of SUS316L powder. 